\title{
Microbial Populations and Enzymatic Activities as Parameters for Characterization of the Composting Process
}

\author{
A. I. Khalil ${ }^{1,2}$, A. R. Bin $\mathrm{Ali}^{2}$ and M. M. Yaqub ${ }^{2}$
}

\begin{abstract}
Changes in microbial populations and enzymatic activities during composting process of municipal solid wastes were investigated. Changes in some physical and chemical parameters were also determind. The results showed that the temperature reached the maximum $(57.5$ $\left.{ }^{\circ} \mathrm{C}\right)$ after 15 days and then decreased. Marked changes in pH value were found. The organic matter (OM) decreased from $61.52 \%$ to $48.92 \%$ and the the loss in OM reached to 40.1\%. The carbon/nitrogen $\mathrm{C} / \mathrm{N}$ ratio decreased from 25.70 to 11.82. The populations of mesophilic bacteria, actinomycetes, and fungi were greatly decreased with time. The thermophilic bacteria reached the maximum after 30 days and then decreased. The thermophilic actinomycetes reached the maximum after 10 days and then decreased with time until 60 days and disappeared after that. The population of thermophilic fungi reached the maximum after 10 days and disappeared after that. The activity of áamylase, carboxymethylcellulase (CMCase) and xylanase enzymes was increased and reached the maximum after 10, 20 and 30 days respectively then was decreased.
\end{abstract}

\section{INTRODUCTION}

The large amounts of municipal solid wastes (MSW) produced in modern society, as well as its disposal, represent a serious environmental, social and economic problem (Castaldi et al., 2008). Environmental acceptable management of MSW has become a global challenge due to limited resource an exponentially increasing population, rapid urbanization and worldwide industrialization (Gautam et al., 2010). Production of MSW, including organic waste is increasing while soils are progressively losing organic matter due to intensive cultivation and climatic conditions. This makes the recycling of organic waste as soil amendments a useful alternative to incineration, landfill or rubbish dumps (Massiani and Domeizel, 1996).

Composting can be regarded as the most usual method for recycling the organic fraction of MSW since it provides an agricultural amendment capable of mitigating the serious deficit of organic matter in many agricultural soils, caused by the low use of organic materials in the fertilization programmes of crops (Canet and Pomares, 1995). Composting is an aerobic process by which organic materials are degraded through the activities of successive groups of microorganisms. It is an environmentally sound method to reduce the adverse impacts of organic wastes and produce organic fertilizer or soil conditioner (Gajdos, 1992).

Changes of temperature during composting process is used regularly to evaluate the maturity of composts (Bustamante et al., 2008). Also The $\mathrm{C} / \mathrm{N}$ ratio is often used as an index of compost maturity, despite many pitfalls associated with this approach, but it seems to be a reliable parameter for following the development of the composting process (Inbar et al., 1990). During composting, organic matter is transformed into a humusrich product by the action of microorganisms and their enzymes. Most of the modifications that organic matter undergoes during composting are mediated by enzymes (Vargas-García et al., 2010). Decomposition of organic matter to usable compost depends on the abilities of the microflora to produce and excrete specific degradative enzymes (Hankin et al., 1976). In the process of composting, the succession of various microbial groups plays a crucial role, and the appearance of nutritionally specialized microbial groups reflects the maturity of composts (Goyal et al., 2005). Therefore, monitoring of the microbial succession may provide important information for the effective management of the composting process and the appearance of certain groups of microorganisms is believed to reflect the degree of stabilization of the organic matter during the process (Ryckeboer et al., 2003).

Microbial enzymes are capable of degrading large organic molecules with complex structures into simple water-soluble compounds composed of small molecules (Castaldi et al., 2008). Therefore, characterizing microbial communities along the composting process may provide valuable information regarding the evolution of the process, the rate of biodegradation and, finally, the maturity of the product (Herrmann and Shann, 1997; Ryckeboer et al., 2003). Microbial activity is achieved through the action of the enzymes that are responsible for the hydrolysis of complex macromolecules that constitute the organic wastes

\footnotetext{
${ }^{1}$ Department of Environmental Studies, Institute of Graduate

Studies and Research, University of Alexandria, Alexandria, Egypt.

E-mail: khalilaii@yahoo.com

${ }^{2}$ Department of Environmental Sciences, Faculty of Natural

Resources and Environmental Sciences, University of

Omar Al-Mukhtar, Al-Bayda, Libya.

Received November 01, 2012, Accepted December 27, 2012.
} 
(Vargas-Garcia et al., 2010). Characterizing and quantifying the enzymatic activities during composting can reflect the dynamics of the composting process in terms of the decomposition of organic matter (Goyal et $a l ., 2005)$ and may provide information about the stability (Mondini et al., 2004) and maturity of compost (Tiquia, 2002). Since organic substrates are characterized by a high complexity, their complete biotransformation during composting demands the joint action of many different enzymes (Vargas-García et al., 2010).

Generally, most studies in composting have focused on physico-chemical parameters to evaluate both process evolution and compost quality (Said-Pullicino $e t$ al., 2007; Albrecht et al., 2008; Aslam et al., 2008). Microorganisms and their enzymatic activities have also recently arisen as good indicators of the stability and maturity of compost because of their key roles in organic matter decomposition during the composting process (Cunha-Queda et al., 2007; Raut et al., 2008; Vargas-Garcia et al., 2010; Liu et al., 2011). Consequently, the aim of this study was to evaluate the changes in microbial populations and their enzymatic activities during the composting of municipal solid waste.

\section{MATERIALS AND METHODS}

\section{Composting methods:}

Municipal solid wastes (MSW) used in this study were collected from the town of Al-Bayda, Libya, and transferred to the compost plant. After sorting, the organic fraction was transferred to a rotating drum (classifier) which tears off the organic material into small pieces to produce the compostable material. After the partial fermentation (5 days) of the compostable material in the compost plant (because the plant does not work all the time and if worked the fermentation was not completed), it transferred to the experimental site (The Farm of Faculty of Natural Resources and Environmental Sciences, University of Omar AlMukhtar, Libya) and piled to a windrow (3.0 $\mathrm{m}$ in width, $1.5 \mathrm{~m}$ in height and $5.0 \mathrm{~m}$ in length) in almost triangular shape and moistened to $40-60 \%$ and then water was added when necessary. The windrow was turned every 10 days during the first two months (fermentation period). Then, the produced compost was allowed to mature for one month (without turning or adding water). The experimental period lasted for 90 days.

\section{Sampling procedure:}

The compost samples were taken from six places at random at a depth of $50 \mathrm{~cm}$ and mixed together. The composite sample was transferred aseptically in closed bag under cooling to the laboratory for analyses.
Sampling was carried out twice a week for determination of moisture content and $\mathrm{pH}$ and every 10 days for the chemical, microbial and enzymatic analyses.

\section{Analytical methods:}

Physical analysis:

The temperature was monitored near the center of the pile with a metal probe thermometer (Poincelot and Day, 1973). It was checked twice a week at five points along the pile.

\section{Chemical analysis:}

The $\mathrm{pH}$ was determined by shaking $5.0 \mathrm{~g}$ compost in $50.0 \mathrm{ml}$ distilled water $(1: 10, \mathrm{w} / \mathrm{v})$ for $30 \mathrm{~min}$, then the $\mathrm{pH}$ was measured (Albonetti and Massari, 1979). The ash content was determined after drying the sample at $105{ }^{\circ} \mathrm{C}$ and ashing at $550{ }^{\circ} \mathrm{C}$ in a muffle furnace for about $3 \mathrm{~h}$. The organic matter (OM) and organic carbon (OC) were estimated as follows: OM $(\%)=100$ - ash $(\%)$, OC $(\%)=$ OM $(\%) / 1.8$ (WHO, 1978). The total nitrogen $(\mathrm{N})$ was determined by the Kjeldahl method, while the $\mathrm{C} / \mathrm{N}$ ratio was calculated using values of the organic carbon and the Kjeldahl total nitrogen (WHO, 1978). The loss of organic matter (OM) was calculated according to the following equation (Paredes et al., 2000): OM - loss $(\%)=100-100\left[\left(\mathrm{X}_{1} \mathrm{OM}_{2}\right) /\left(\mathrm{X}_{2} \mathrm{OM}_{1}\right)\right]$; where: $X_{1}$ and $X_{2}$ are the initial and final ash concentrations, and $\mathrm{OM}_{1}$ and $\mathrm{OM}_{2}$ are the initial and final OM concentrations. All determinations were carried out in triplicate.

\section{Microbiological analysis:}

The populations of mesophilic and thermophilic bacteria; actinomycetes and fungi were determined. The microbial enumeration was measured with spread plate counting method. Thus, $10 \mathrm{~g}$ of each fresh sample was mixed with $90 \mathrm{ml}$ sterilized saline solution, shaken for $30 \mathrm{~min}$ and serial dilutions $\left(10^{-2}-10^{-7}\right)$ were then prepared. Suitable media were used for the enumeration of the different groups of microorganisms. Nutrient agar (NA), malt-yeast extract agar (MYEA) and potato dextrose agar (PDA) media were used for bacteria, actinomycetes and fungi, respectively. The incubation temperature was $30{ }^{\circ} \mathrm{C}$ for isolation of mesophiles and $50{ }^{\circ} \mathrm{C}$ for thermophiles. The incubation period time was 3 days for mesophilic bacteria, 2 days for thermophilic bacteria and 7 days for actinomycetes and fungi, either mesophilic and thermophilic. The average number of microorganisms isolated on three plates was expressed as colony-forming units (CFU) per oven-dried weight of compost.

\section{Enzymatic analysis:}

The enzymatic activities were determined using aqueous compost extracts. Thus, $10 \mathrm{~g}$ of each fresh sample was transferred to a flask containing $50 \mathrm{ml}$ 
acetate buffer (0.1 M, pH 5.0). The flask was shaken at $150 \mathrm{rpm}$ for $1 \mathrm{~h}$. The flask content was clarified by filtration through cheese cloth, and then $10 \mathrm{ml}$ of the filtrate was centrifuged at $4^{\circ} \mathrm{C}$ for $15 \mathrm{~min}$ at $5000 \mathrm{rpm}$. Subsequently, the supernatant was used for measurement of enzymatic activity. The assay of $\alpha$-amylase, carboxymethylcellulase (CMCase) and xylanase activity was carried out by measuring the reducing sugars as described by Shambe and Ejembi (1987). All determinations were carried out in triplicate.

\section{Statistical analysis:}

One-way analysis of variance (ANOVA) was used to compare mean values from different samples. Where significant differences were obtained, individual means were tested using the Least Significance Difference test $(P<0.05)$. The relationship between the composting time and temperature, microbial populations, enzymatic activities and $\mathrm{C} / \mathrm{N}$ ratio was evaluated by using Pearson correlation analysis providing a correlation coefficient (" $r$ "), where positive and negative $r$ values denoted positive and negative correlations, respectively.

\section{RESULTS AND DISCUSSION}

\section{Temperature:}

The changes in temperature during the composting process are shown in Figure 1A. The ambient temperature was about $30 \pm 3{ }^{\circ} \mathrm{C}$ in the day and $20 \pm 3$ ${ }^{\circ} \mathrm{C}$ in the night. Temperature of the windrow gradually increased from $34{ }^{\circ} \mathrm{C}$ and reached the maximum value $\left(57.5{ }^{\circ} \mathrm{C}\right)$ after 15 days of composting. Then, the temperature gradually decreased and reached to $35{ }^{\circ} \mathrm{C}$ by the end of the composting period. Generally, the increase in temperature after 15 days may be attributed to the abundant of active indigenous microorganisms in the raw composting materials and to the suitability of composting conditions (moisture content, aeration, pile size) for microbial and enzymatic activities. On the other hand, the decrease in temperature after that may be attributed to the decrease of microbial population and enzymatic activities due to that most of the easily degradable organic matter had been metabolized. The results revealed that the temperature was negatively correlated with the composting time $(r=-0.686, p<$ $0.01)$. This type of correlation indicates that the temperature moderately decreased by the end of composting as the compost reached to the maturity. It can be seen that the changes in temperature during the composting process followed a pattern typical for many composting processes as described by several authors (Poincelot, 1974; Inbar et al., 1993; Khalil et al., 2001; Shaheen, 2007).

It was noticed that the temperature increased from 40 to $60{ }^{\circ} \mathrm{C}$ in about 60 days which is suitable with other parameters such as moisture content and aeration for microbial and enzymatic activities and therefore the increase of organic matter decomposition. The peak of temperature recorded during the present study was 57.5 ${ }^{\circ} \mathrm{C}$. It is generally agreed that the temperature of the composting process should not exceed $60{ }^{\circ} \mathrm{C}$ to avoid thermal inactivation of the desired microbial community necessary for the efficient degradation of organic wastes (Fogarty and Tuovinen, 1991). Consequently, this parameter may be considered a good indicator of the end of the biooxidative phase in which the compost achieves some degree of maturity (Jiménez and Garcia, 1989).

pH:

The average changes in $\mathrm{pH}$ value during the composting process are shown in Figure 1B. The starting $\mathrm{pH}$ value was 7.9. After 3 days of composting, the $\mathrm{pH}$ decreased slightly to 7.75 and then gradually increased and reached the maximum value (9.03) after 10 days. Afterwards it decreased gradually and reached to 7.50 by the end of composting. It is found that the $\mathrm{pH}$ was near the neutrality then increased with time to the alkalinity and returned again to the neutrality at the end of composting. The slight alkalinization occurred as soon as the mass temperature increased, whereas during the cooling down it decreased to near the neutral value and then stabilized. Generally, the pattern of $\mathrm{pH}$ during the composting process was typical for many composting processes as described by several authors (Chang and Hudson, 1967; Poincelot, 1974; Inbar et al., 1993). It was reported that the decrease in $\mathrm{pH}$ during the first period of composting is expected because of the acids formed during the metabolism of readily available carbohydrates. After this initial stage, the $\mathrm{pH}$ is expected to rise, with evolution of free ammonia and to stabilize or drop slightly again to near neutral as a result of humus formation with its pH-buffering capacity at the termination of composting activity (Poincelot, 1974; Fogarty and Tuovinen, 1991).

\section{Organic matter (OM):}

The results showed that $\mathrm{OM}$ decreased gradually by time then from $61.52 \%$ to $48.92 \%$ (Figure $2 \mathrm{~A}$ ). By the end of composting, the loss in OM reached to $40.1 \%$ from the starting value (Figure 2B). The OM degradation was revealed by the OM loss, which is directly related to microbial respiration as mentioned by Paredes et al. (2002). The composting of most substrates is characterized by an initial period of rapid degradation followed by a longer period of slow degradation (Diaz et al., 2002). The OM degradation profile during composting, as determined by OM loss, follows a firstorder kinetic equation (Figure 2B) and this is in agreement with that found by Paredes et al. (2002) and Serramiá et al. (2010). 

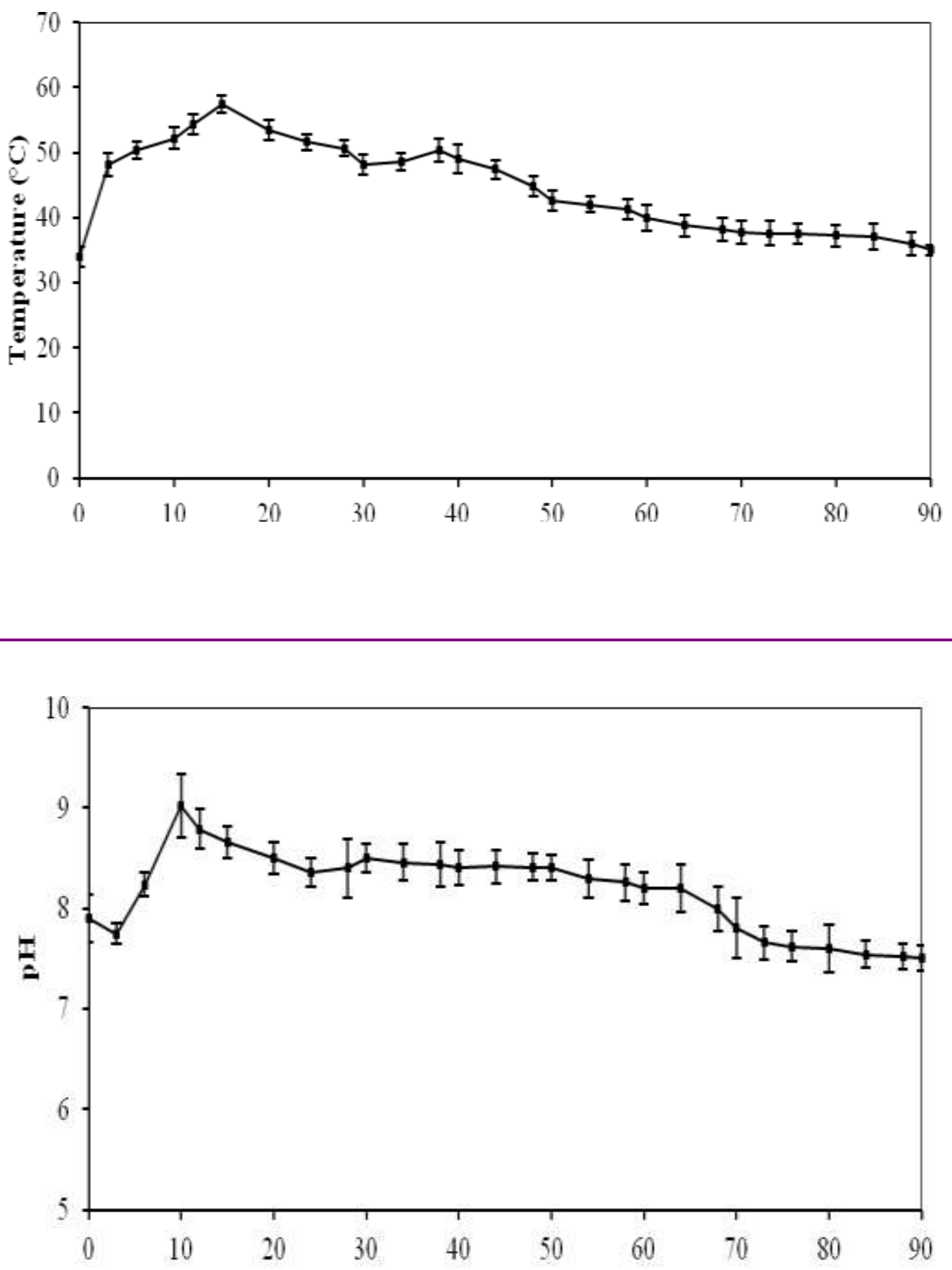

Composting time(Days)

Figure 1. Changes in temperature $\left({ }^{\circ} \mathrm{C}\right)(\mathrm{A})$ and $\mathrm{pH}(\mathrm{B})$ during the composting of municipal solid wastes. Temperature's values are means of five replicates \pm standard deviations. $\mathrm{PH}$ values are means of three replicates \pm standard deviations 

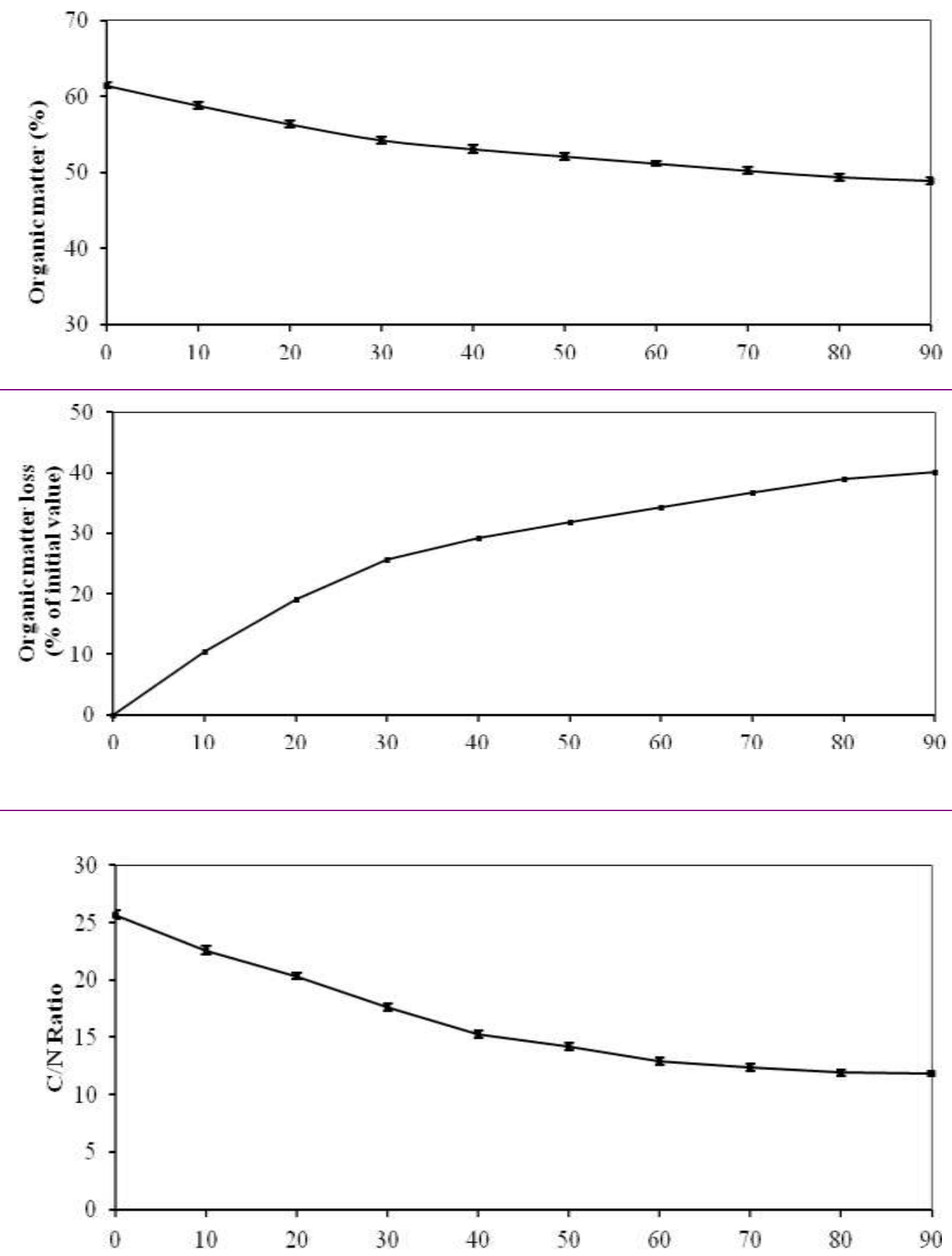

Composting time (Days)

Figure 2. Changes in organic matter $(\%)^{*}(\mathrm{~A})$, organic matter loss $(\%)(\mathrm{B})$ and $\mathrm{C} / \mathrm{N}$ ratio ${ }^{*}$ (C) during composting of municipal solid wastes. "Values are means of three replicates \pm standard deviations. 


\section{C/N ratio:}

The results showed that the $\mathrm{C} / \mathrm{N}$ ratio decreased gradually by time. It decreased from 25.7 to 11.82 by the end of composting (Figure 2C). The results revealed that significant differences were found between the values of $\mathrm{C} / \mathrm{N}$ ratios with time. $\mathrm{C} / \mathrm{N}$ ratio was negatively correlated with time $(r=-0.967, p<0.01)$. This type of correlation indicates that the $\mathrm{C} / \mathrm{N}$ ratio decreased by the end of composting as indicator for the compost maturity. As the decomposition progressed due to losses of carbon mainly as carbon dioxide, the carbon content of the compostable material decreased with time and $\mathrm{N}$ content per unit material increased, which resulted in the decrease of $\mathrm{C} / \mathrm{N}$ ratio (Goyal et al., 2005). It has been stated that the $\mathrm{C} / \mathrm{N}$ ratio of mature compost should ideally be about 10 but this is hardly ever achievable, due to the presence of recalcitrant organic compounds, or materials which resist decomposition due to their physical or chemical properties (Mathur, 1991). It was reported that a $\mathrm{C} / \mathrm{N}$ ratio below 20 is indicative of an acceptable maturity (Poincelot, 1974), a ratio of 15 or even less being preferable (Jiménez and Garcia, 1989). The $\mathrm{C} / \mathrm{N}$ ratio of compost cannot be used as an absolute indicator of the state of maturation since the $\mathrm{C} / \mathrm{N}$ ratio found in well-composted materials presents great variability due, above all, to the type of original material (Hirari et al., 1983). Generally, the decrease in $\mathrm{C} / \mathrm{N}$ ratio can be taken as a reliable index of compost maturity when combined with other parameters as mentioned by Goyal et al. (2005).

\section{Microbial populations:}

The changes in the number of mesophilic and thermophilic microorganisms during the composting process are presented in Figure 3. The figure shows the logarithm of the number present. As shown in Figure $3 \mathrm{~A}$, the number of mesophilic bacteria gradually decreased with time until 60 days and a slight increase was found when the temperature was decreased below $40{ }^{\circ} \mathrm{C}$ (during the maturation period). The same trend was found by several investigators (Chang and Hudson, 1967; Hassen et al., 2001; Shaheen, 2007). Chang and Hudson (1967) noticed a reduction in numbers of mesophilic bacteria during the high temperature phase $\left(55-70{ }^{\circ} \mathrm{C}\right)$, but when the temperature falls below this, there was a striking development of these mesophiles. They also reported that the mesophilic bacteria behave more like the thermophilic fungi than the mesophilic ones and this may in part be due to the fact that they have high maximum growth temperatures. On the other hand, the thermophilic ones increased with time and reached the maximum number after 30 days and then gradually decreased by the end of composting (Figure
3A). Similar results were found by many investigators (Chang and Hudson, 1967; Khalil et al., 2001; Shaheen, 2007). The number of mesophilic actinomycetes gradually decreased with time until 60 days and disappeared after that (Figure 3B). It was mentioned that the occurrence of mesophilic actinomycetes was irregular for any consistent pattern to be observed (Chang and Hudson, 1967). On the other hand, the thermophilic ones increased and reached the maximum number after 10 days and then gradually decreased with time until 60 days and disappeared after that (Figure 3B). The same trend was found by Chang and Hudson (1967) and Nakasaki et al. (1985). The mesophilic fungi gradually decreased with time until 40 days and disappeared after that (Figure 3C). Close results were found by some researchers (Khalil et al., 2001; Shaheen, 2007). The thermophilic fungi slightly increased and reached the maximum number after 10 days and disappeared after that (Figure 3C). The result found agrees with that found by Shaheen (2007). The results revealed that significant differences were found between the microbial numbers with time. The correlation between the number of microbes with time was strong from the negative type in case of mesophilic bacteria ( $r=$ $-0.858, p<0.01)$ and mesophilic and thermophilic fungi $(r=-0.806$ and $-0.862, p<0.01)$ and medium from the negative type in case of mesophilic and thermophilic actinomycetes $(r=-0.433$ and $-0.406, p<0.01)$. On the other hand, the correlation was weak from the positive type in case of thermophilic bacteria $(r=0.079, p<$ 0.01 ).

It can be also realized from these data that the most common microorganisms in the composting process are bacteria and actinomycetes (mesophilic and thermophilic). The mesophilic and thermophilic fungi had a short time span in the composting process. Bacteria flourished because of their ability to grow rapidly on soluble proteins and other readily available substances and because they are the most tolerant to high temperature as mentioned by Miller (1992). It was interesting to find quite lots of mesophilic bacteria existed at thermophilic range, which might be resulted from their thermotolerance property as mentioned by Ma et al. (2003) who found quite lots of mesophilic bacteria at thermophilic range $\left(56-60{ }^{\circ} \mathrm{C}\right)$. Although a large number of mesophilic bacteria could be isolated from the composted materials even at thermophilic range of 60 ${ }^{\circ} \mathrm{C}$, their respiratory activity at $60{ }^{\circ} \mathrm{C}$ was found to be negligible (Nakasaki et al., 1985). Moreover, it was stated that most fungi are eliminated at temperatures above $50{ }^{\circ} \mathrm{C}$; only a few have been isolated from compost that can grow at all up to $62{ }^{\circ} \mathrm{C}$. Their survival was due to their thermotolerance property. During 
composting, temperatures above $55{ }^{\circ} \mathrm{C}$ discourage fungal growth. Fungi are excluded from waste composting during the earlier high temperature stage (Miller, 1992). The disappearance or decrease of fungi could be attributed to the effect of $\mathrm{pH}(>7.0)$ as found in this study, because the fungi favour an acidic $\mathrm{pH}$ range as mentioned by Fogarty and Tuovinen (1991). Generally, mesophilic microorganisms are responsible for the initial decomposition of organic materials and the generation of heat responsible for the increase in compost temperature (Fogarty and Tuovinen, 1991). As the temperature begins to rise, thermophilic microorganisms begin to dominate, while during the cooling phase of composting, mesophilc microorganisms reappear again (Poincelot, 1974; Fogarty and Tuovinen, 1991). The microbial biomass of some groups of microorganisms, especially thermophilic bacteria, decreases in the last phases of composting as the product reaches maturity, so that a total count of microorganisms (principally bacteria) throughout the process can be indicative to the state of compost maturity (Jiménez and Garcia, 1989).

\section{Enzymatic activities:}

Complex organic molecules are broken down to simpler components during composting (Zameer et al., 2010). Microbes reproduced in the composting pile metabolize insoluble particles of organic matter by secreting different hydrolytic enzymes. These various hydrolytic enzymes are thought to control the degradation rates of different substrates, and they are the main mediators of various degradation processes (Tiquia, 2002). Measurement of enzyme activity is helpful in understanding microbial metabolism during composting (Ma et al., 2003; Mondini et al., 2004). Monitoring of various enzymatic activities throughout the process provides useful information on the dynamics of important nutritional elements such as $\mathrm{C}$ and $\mathrm{N}$ and is beneficial for understanding the transformations occurring during composting (Vargas-García et al., 2010). Therefore, different enzymatic activities were measured to find out which enzymes participate in the bioconversion of the given organic waste material. Due to the complex composition of the composting mixture, the enzymatic activities to be measured were chosen according to the presence of their possible inducers such as starch, cellulose and hemicellulose. So, the changes in the activities of three important enzymes; á-amylase, CMCase and xylanase which are responsible for hydrolysis of starch, cellulose and hemicellulose, respectively, were studied to understand the degradation of organic wastes during the composting process.

As shown in Figure 4, the activity of á-amylase, CMCase and xylanase increased and reached the maximum values $(3.78,3.47$ and $1.75 \mathrm{ig} / \mathrm{ml} / \mathrm{min})$, respectively after 10, 20 and 30 days, respectively and then gradually decreased with time. There was no activity for the three enzymes after 90 days (the end of composting). It is noticed from the results obtained that the activities of the enzymes reached the maximum as soon as the mass temperature increased. Also, the activiies of these enzymes were related to the number of microorganisms. Generally, the results showed that the highest microbiological populations as well as the enzymatic activities occurred during the thermophilic phase $\left(>40{ }^{\circ} \mathrm{C}\right)$ of the process. The results revealed that significant differences were found between the enzymatic activities with time. The correlation between the enzymatic activities with time was medium from the negative type. It was $(r=-0.470,-0.495$ and $-0.616, p$ $<0.01$ ) in case of á-amylase, CMCase and xylanase, respedtively. This type of correlation indicates that the enzymatic activities decreased by the end of composting as indicator for the compost maturity.

The maximum activity of á-amylase occurred after 10 days of composting (Figure 4A) and this may be attributed to the starchy materials which are degraded faster than other materials (cellulose and hemicellulose). Similar result was found by Raut et al. (2008) who stated that the maximum activity of á-amylase occurred after 9 days and declined after that. It was mentioned that early degradation of starch could have been attributed as a result of increasing microbial biomass during this initial phase (Raut et al., 2008). Recently, Zameer et al. (2010) stated that the activity of amylase was highest during the initial stage and lowest during the final stage of composting. The lower activity during the final stage indicates the mere completion of decomposition process. The activity of CMCase increased and reached the maximum after 20 days of composting and then decreased by the end of composting (Figure 4B). Similar result was found by Khalil et al. (2001) who stated that the activity of CMCase of compost extracts increased and reached the maximum value after 3 weeks and then decreased by the end of composting. Goyal et al. (2005) stated that the maximum activity of cellulase as CMCase was found after 30 days and declined later on. Shaheen (2007) mentioned also that the activity of CMCase increased and reached the maximum value after 30-40 days and then decreased. Initial low CMCase activity could be attributed to the availability of simple compounds to the living microorganisms and the subsequent higher activity at the lower $\mathrm{C} / \mathrm{N}$ ratio may be attributed to the greater nitrogen availability as mentioned by Ashbolt and Line (1982). The activity of xylanase increased and reached the maximum after 30 days of composting and then decreased by the end of 

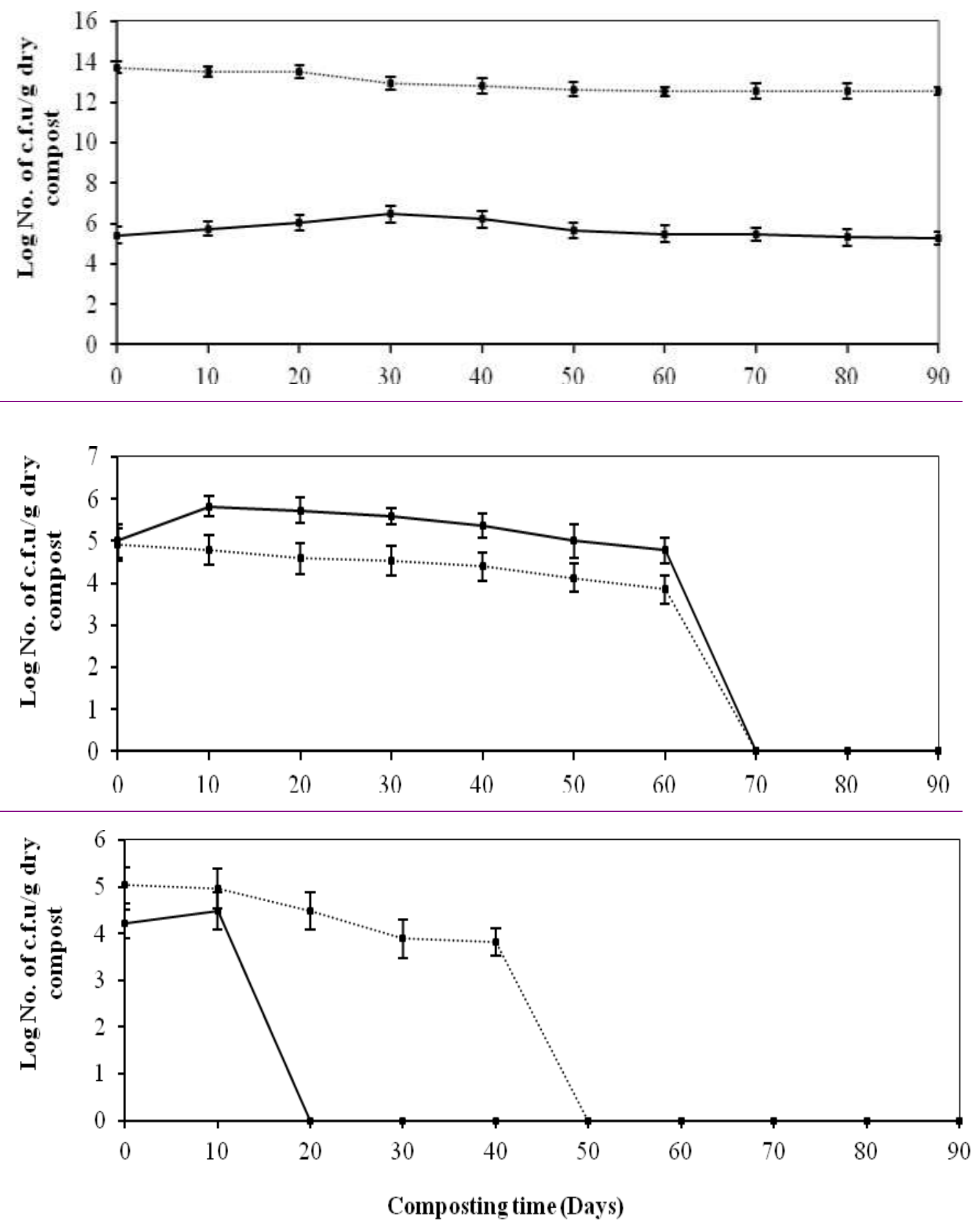

............ Mesophilic $\rightarrow$ Thermophilic

Figure 3. Changes in counts of mesophilic and thermophilic bacteria (A), actinomycetes (B) and fungi $(\mathrm{C})$ during the composting of municipal solid wastes. Values are means of three replicates \pm standard deviations. $c$.f.u. colony-forming units 

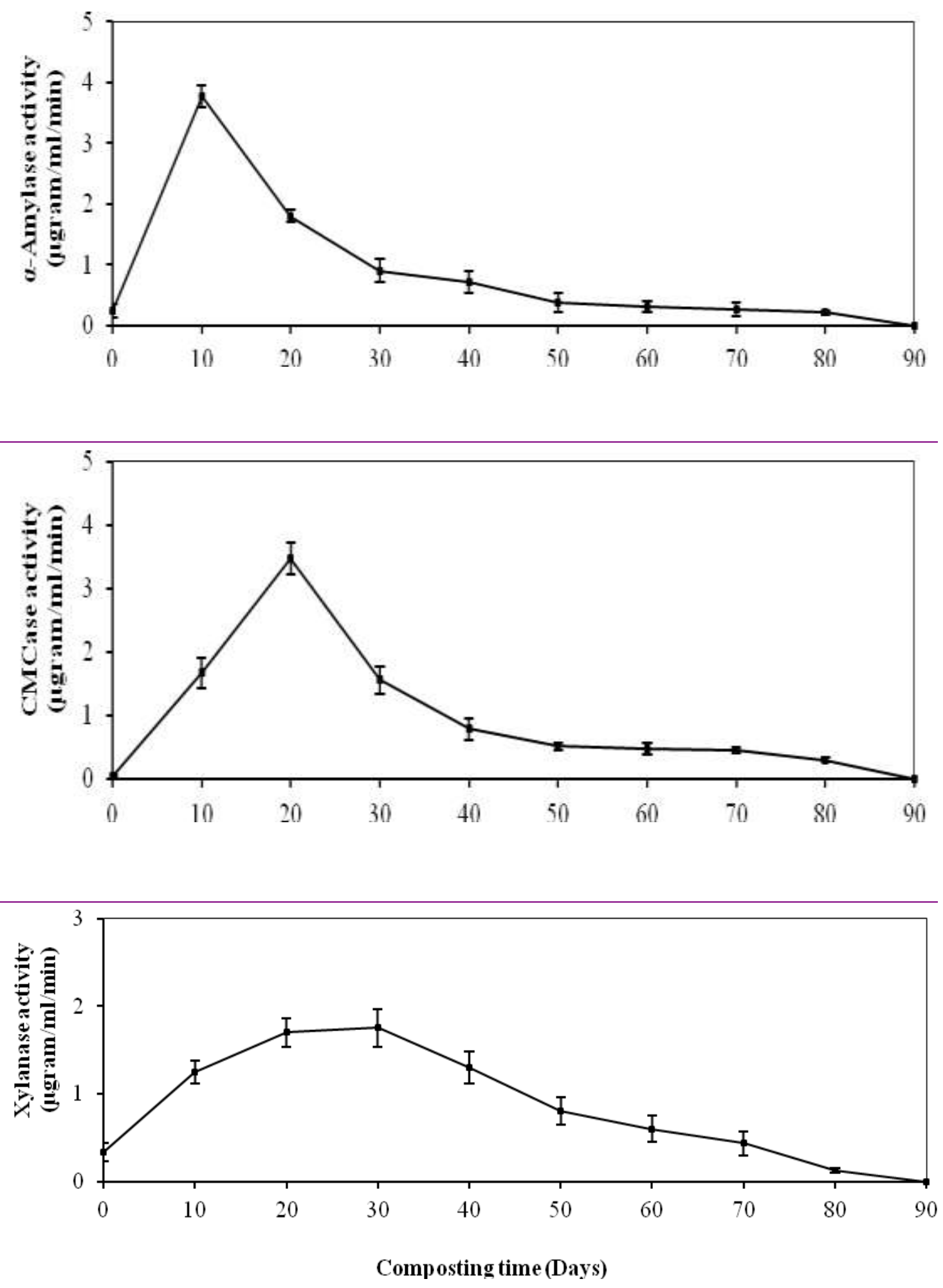


\section{Figure 4. Changes in á-amylase (A), carboxymethylcellulase (CMCase) (B) and xylanase (C) activity during the composting of municipal solid wastes. Values are means of three replicates \pm standard deviations.}

composting (Figure 4C). Similar result was found by Shaheen (2007) who stated that the activity of xylanase increased and reached the maximum value after 30 days and then decreased. On the other hand, it was mentioned that the maximum activity of xylanase was found after 60 days and declined after that (Goyal et al., 2005).

It was found that the activity of such enzymes towards the end of the composting period decreased and stabilized. The enzymes enumerated can be taken into consideration in estimation of the compost maturity. Generally, the hydrolytic activities monitored in this study were able to reveal the dynamics of the organic matter degradation during the composting process of the municipal solid waste used in this work.

\section{CONCLUSIONS}

From the results obtained in this study, it can be concluded that microbial populations and enzymatic activities during composting could be used as suitable indicators to characterize the composting process and compost maturity. Adjustment of composting conditions such as aeration, moisture content and temperature is very important. This would allow for microbial populations and their enzymatic activities to increase and therefore the increase of organic matter decomposition as a reduction in $\mathrm{C} / \mathrm{N}$ ratio and then the composting time can be reduced. Therefore, the changes in microbial populations and their enzymatic activities during composting could be used as suitable indicators to characterize the composting process and compost maturity when combined with other parameters such as temperature and $\mathrm{C} / \mathrm{N}$ ratio.

\section{REFERENCES}

Albonetti, S.G.and Massari, G. (1979). Microbiological aspects of a municipal waste composting system. European Journal of Applied Microbiology and Biotechnology 7, 91-98.

Albrecht, R., Joffre, R., Gros, R., Le Petit, J., Terrom, G. and Périssol, C. (2008). Efficiency of near-infrared reflectance spectroscopy to asses and predict the stage of transformation of organic matter in the composting process. Bioresource Technology 99, 448-455.

Ashbolt, N.J. and Line, M.A. (1982). A bench-scale system to study the composting of organic wastes. Journal of Environmental Quality 11, 405-408.

Aslam, D.N., Horwath, W. and VanderGheynst, J.S. (2008). Comparison of several maturity indicators for estimating phytotoxicity in compost-amended soil. Waste Management 28, 2070-2076.
Bustamante, M.A., Moral, R., Paredes, C., Vargas-García, M.C., Suárez-Estrella, F. and Moreno, J. (2008). Evolution of the pathogen content during co-composting of winery and distillery wastes. Bioresource Technology 99 (15), 7299-7306.

Canet, R. and Pomares, F. (1995). Changes in physical, chemical and physico-chemical parameters during the composting of municipal solid wastes in two plants in Valencia. Bioresource Technology 51, 259-264.

Castaldi, P., Garau, G. and Melis, P. (2008). Maturity assessment of compost from municipal solid waste through the study of enzyme activities and water-soluble fractions. Waste Management 28, 534-540.

Chang, Y. and Hudson, H.J. (1967). The fungi of wheat straw compost. I. Ecological studies. Translations of British Mycological Society 50, 649-666.

Cunha-Queda, A.C., Ribeiro, H.M., Ramos, A. and Cabral, F. (2007). Study of biochemical and microbiological parameters during composting of pine and eucalyptus bark. Bioresource Technology 98, 3213-3220.

Diaz, M.J., Madejon, E., Lopez, F., Lopez, R. and Cabrera, F. (2002). Optimization of the rate vinasse/grape marc for co-composting process. Process Biochemistry 37, 11431150.

Fogarty, A.M. and Tuovinen, O.H. (1991). Microbiological degradation of pesticides in yard waste composting. Microbiological Reviews 55(2), 225-233.

Gajdos, R. (1992). The use of organic waste materials as organic fertilisers-recycling of plant nutrients. Acta Horticulurae 302, 325-331.

Gautam, S.P., Bundela, P.S., Pandey, A.K., Awasthi, M.K. and Sarsaiya, S. (2010). Microbial consortium for effective composting of municipal solid waste by enzymatic activities. Journal of Applied Sciences in Environmental Sanitation 5 (3), 301-308.

Goyal, S., Dhull, S.K. and Kapoor, K.K. (2005). Chemical and biological changes during composting of different organic wastes and assessment of compost maturity. Bioresource Technology 96, 1584-1591.

Hankin, L., Anagnostakis, S.L. and Poincelot, R.P. (1976). Compost by biodegradation of leaves. In: Miles Sharpley, J. and Kaplan, A.M. (eds.). Proceedings of the Third International Biodegradation Symposium. Applied Science Publishers LTD, London, pp. 701-709.

Hassen, A., Belguith, K., Jedidi, N., Cherif, A., Cherif, M. and Boudabous, A. (2001). Microbial characterization during composting of municipal solid waste. Bioresource Technology 80, 217-225. 
Hermann, R.F. and Shann, J.F. (1997). Microbial community changes during the composting of municipal solid waste. Microbial Ecology 33, 78-85.

Hirari, M., Chanyasak, V. and Kubota, H. (1983). A standard measurement for compost maturity. Biocycle 24, 54-56.

Inbar, Y., Chen, Y., Hadar, Y. and Hoitink, H.A.J. (1990). New approaches to compost maturity. Biocycle 31 (12), 64-69.

Inbar, Y., Hadar, Y. and Chen, Y. (1993). Recycling of cattle manure: the composting process and characterization of maturity. Journal of Environmental Quality 22, 857-863.

Jiménez, E.I. and Garcia, V.P. (1989). Evaluation of city refuse compost maturity: a review. Biological Wastes 27, $55-142$.

Khalil, A.I., Beheary, M.S. and Salem, E.M. (2001) Monitoring of microbial populations and their cellulolytic activities during the composting of municipal solid wastes. World Journal of Microbiology and Biotechnology 17, $155-161$

Liu, D., Zhang, R., Wu, H., Xu, D., Tang, Z., Yu, G., Xu, Z. and Shen, Q. (2011). Changes in biochemical and microbiological parameters during the period of rapid composting of dairy manure with rice chaff. Bioresource Technology 102, 9040-9049.

Ma, Y., Zhang, J.Y. and Wong, M.H. (2003). Microbial activity during composting of anthracene-contaminated soil. Chemosphere 52, 1505-1513.

Massiani, C. and Domeizel, M. (1996). Quality of compost organic matter stabilization and trace metal contamination. In: De Bertoldi, M., Sequi, P., Lemmes, B. and Papi, T. (eds.). The Sciences of Composting. Blackie Academic and Profissional, Glasgow, UK, pp. 185-194.

Mathur, S.P. (1991). Composting processes. In: Martin, A.M. (ed.). Bioconversion of Waste Materials to Industrial Products. Elsevier Applied Science Publishers, London, pp. 147-183.

Miller, F.C. (1992). Biodegradation of solid wastes by composting. In: Martin, A.M. (ed.). Biological Degradation of Wastes. Elsevier Applied Science Publishers, London, pp. 1-30.

Mondini, C., Fornasier, F. and Sinicco, T. (2004). Enzymatic activity as a parameter for the characterization of the composting process. Soil Biology and Biochemistry 36, 1587-1594.

Nakasaki, K., Sasaki, M., Shoda, M. and Kubata, H. (1985). Change in microbial numbers during thermophilic composting of sewage sludge with reference to $\mathrm{CO} 2$ evolution rate. Applied and Environmental Microbiology 49(1), 37-41.

Paredes, C., Bernal, M.P., Cegarra, J. and Roig, A. (2002). Bio-degradation of olive mill wastewater sludge by its cocomposting with agricultural wastes. Bioresource Technology 85, 1-8.

Paredes, C., Roig, A., Bernal, M.P., Sánchez- Monedero, M.A. and Cegarra, J. (2000). Evolution of organic matter and nitrogen during co-composting of olive mill wastewater with solid organic wastes. Biology and Fertility of Soils 3, 222-227.

Poincelot, R.P. (1974). A scientific examination of the principles and practice of composting. Compost Science $15,24-31$

Poincelot, R.P. and Day, P.R. (1973). Rates of cellulose decomposition during the composting of leaves combined with several municipal and industrial wastes and other additives. Compost Science 14, 23-25.

Raut, M.P., Prince William, S.P.M., Bhattacharyya, J.K., Chakrabarti, T. and Devotta, S. (2008). Microbial dynamics and enzyme activities during rapid composting of municipal solid waste - a compost maturity analysis perspective. Bioresource Technology 99 (14), 6512-6519.

Ryckeboer, J., Mergaert, J., Coosemans, J., Deprins, K. and Swings, J. (2003). Microbiological aspects of biowaste during composting in a monitored compost bin. Journal of Applied Microbiology 94, 127-137.

Said-Pullicino, D., Erriquens, F.G. and Gicliotti, G. (2007). Changes in the chemical characteristics of waterextractable organic matter during composting and their influence on compost stability and maturity. Bioresource Technology 98, 1822-1831.

Serramiá, N., Sánchez-Monedero, M.A., FernándezHernández, A., García-Ortiz Civantos, C. and Roig, A. (2010). Contribution of the lignocellulosic fraction of twophase olive-mill wastes to the degradation and humification of the organic matter during composting. Waste Management 30, 1939-1947.

Shaheen, M.M. (2007). Environmental Studies on Composting of Municipal Solid Wastes. M. Sc. Thesis, Institute of Graduate Studies and Research, University of Alexandria, Alexandria, Egypt.

Shambe, T. and Ejembi, O. (1987). Production of amylase and cellulose: degradation of starch and carboxymethylcellulose by extracellular enzymes from four fungal species. Enzyme and Microbial Technology 9, 308-312.

Tiquia, S.M. (2002). Evolution of extracellular enzyme activities during manure composting. Journal of Applied Microbiology 92(4), 764-775.

Vargas-García, M.C., Suárez-Estrella, F., López, M.J. and Moreno, J. (2010). Microbial population dynamics and enzyme activities in composting processes with different starting materials. Waste Management 30(5), 771-778.

WHO (1978). Methods of Analysis of Sewage Sludge Solid Wastes and Compost. WHO International Reference Centre for Wastes Disposal. CH-8600, Dübendorf, Switzerland.

Zameer, F., Meghashri, S., Gopal, S., Raghavendra Rao, B. (2010). Chemical and microbial dynamics during composting of herbal pharmaceutical industrial waste. $E$ Journal of Chemistry 7(1), 143-148. 


\section{الملخص العربي}

\section{الأعداد الميكروبية والأنشطة الإنيمية كصفات للحكم على عملية إنتاج الكمبوست}

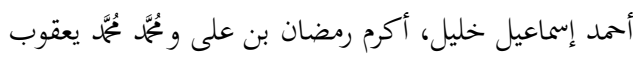

انخفضت الفطريات الثيرموفيلية تدريجياً مع الوقت حتى 40 يوماً

ولم تظهر بعد ذلك في حين أن الفطريات الثيرموفيلية ازدادت ووصلت إلى أقصاها بعد 10 أيام ولم تظهر بعد ذلك.

كما أشارت النتائج أيضاً إلى أن الأنشطة الإنزيمية ازدادت

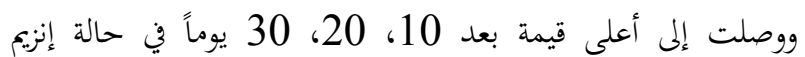
الأميلاز، الكربوكسى ميثايل سليولاز و الزيلاناز، على فئل التوالي ثم انخفضت بعد ذلك، كما لوحظ أنه لا يوجد أي نشاط لهذه الإنزيمات

$$
\text { بنهاية التجربةً. }
$$

نستنتج من النتائج المتحصل عليها أن التغيرات في الأعداد

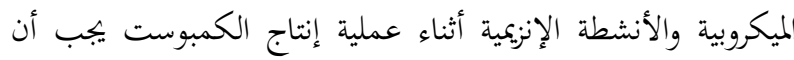

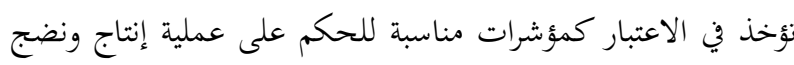
الكمبوست. ضبط ظروف عملية إنتاج الكمبوست مثل التهوية والمحتوى الرطوبي ودرجة الحرارة مهم جداً حيث أن ذلك يسمح

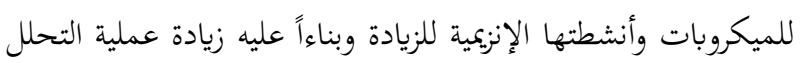

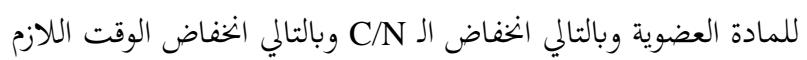

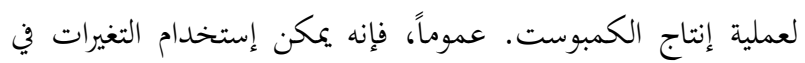

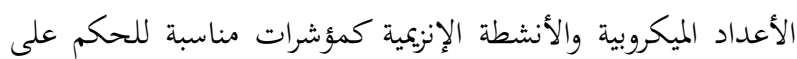
عملية إنتاج الكمبوست ونضجه إذا أخذ في الاعتبار التغيرات في مقاييس أخرى مثل درجة الحرارة و الـ C/N.
أجريت هذه الدراسة لمعرفة التغيرات في الأعداد الميكروبية والأنشطة الإنزيمية أثناء عملية تحويل المخلفات البلدية الصلبة إلى سماد المراد عضوي صناعي (كمبوست) باستخدام طريقة المصفوفة، وذلك لتتبع عملية التحلل ونضج الكمبوست. كما تم رصد التغيرات في بعض الصفات الفيزيائية والكيميائية خلال مدة التجربة (90 يوماً). أشارت النتائج إلى أن درجة الحرارة وصلت إلى أقصاها (57.5

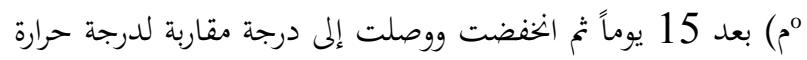

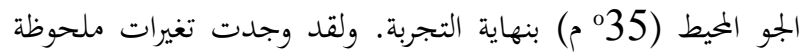
في قيمة رقم الحموضة pH.pH كما حدث الخفاض في نسبة المادة

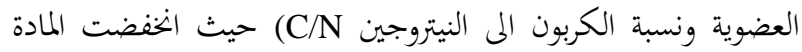
العضوية من 61.52\% إلى 48.92\% ووصل الفقد فيها إلى 40.1\% بنهاية التجربة، في حين انخفضت نسبة C/N من 25.7 إلى 11.82. كما أشارت النتائج إلى أن البكتريا المحبة للحرارة المتوسطة (الميزوفيلية) انخفضت مع الوقت حتى 60 يوماً من بداية عملية التخمر ثم حدثت زيادة طفيفة عندما الخفضت درجة الحرارة إلى 40م في حين ازدادت البكتريا المحبة للحرارة المرتفعة (الثيرموفيلية) ووصلت إلى أقصاها بعد 30 يوماً من بداية عملية التخمر تمدئ

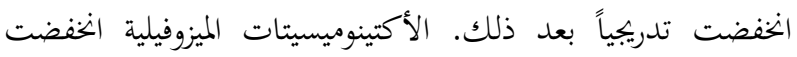

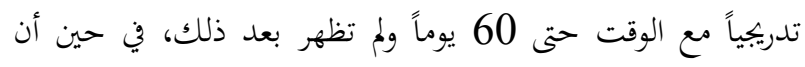
الأكتينوميسيتات الثيرموفيلية ازدادت ووصلت إلى أقصاها بعد 10

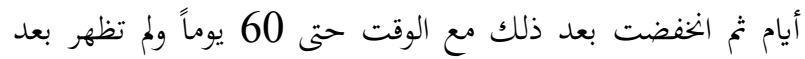
ذلك. 